\title{
PRAKTIK TATA KELOLA PERUSAHAAN (CORPORATE GOVERNANCE)
}

\author{
Ira Hairani Br Damanik \\ Universitas Sumatera Utara \\ Medan \\ Email: irahairanibrdamanik@gmail.com
}

\begin{abstract}
Abstrak
Artikel ini betujuan untuk memahami bagaimana penerapan Good Corporate Governance yang berdampak terhadap nilai perusahaan. Metode artikel ini yaitu menggunakan kajian literatur dengan menggunakan jurnal-jurnal sebagai data analisis. Hasil yang diperoleh adalah bahwa Good Corporate Governance memiliki pengaruh dalam meningkatkan corporate value. Praktik manajemen laba akan berdampak pada kredibilitas laporan keuangan. Kinerja Keuangan dan Kinerja Saham yang dicapai perusahaan tergolong baik, terlihat dari nilai-nilai yang digunakan sebagai indikator untuk merefleksikan Kinerja Keuangan dan Kinerja Saham. Penerapan Tata Kelola Perusahaan seharusnya dapat meningkatkan patuhnya perusahaan terhadap aturan-aturan yang berlaku untuk mencapai tujuan perusahaan.
\end{abstract}

\section{Kata Kunci : Tata Kelola Perusahaan, Kinerja Perusahaan}

\section{PENDAHULUAN}

Laporan keuangan sebagai proses akhir dari manajemen keuangan adalah salah satu sumber utama informasi keuangan yang sangat penting bagi calon investor dan kreditor. Laporan keuangan merupakan media komunikasi yang digunakan untuk menghubungkan pihak yang berkepentingan dengan perusahaan.Karena laporan keuangan berisi informasi tentang kondisi keuangan dan kinerja perusahaan. Selain itu, ketika perusahaan mencapai target kinerjanya, manajemen di perusahaan akan secara otomatis mengubah laporan keuangan dengan memilih dan menerapkan metode manajemen yang dapat menunjukkan bahwa perusahaan telah berhasil mencapai kinerja yang baik dan keuntungan perusahaan juga baik.Terdapat satu hal yang tidak dapat dipisahkan dalam menghubungkan struktur kepemilikan dengan kinerja pada perusahaan. Yaitu kepengurusan dalam manajemen perusahaan itu sendiri. Oleh sebab itu hubungan antara manajemen suatu perusahaan dan pemilik perusahaan akan dibentuk dalam suatu kontrak (performance contract).

Kinerja keuangan juga dipengaruhi oleh tata kelola perusahaan yang baik (GCG). Good Cooperate Governance adalah sistem yang mampu memberikan hak perlindungan dan jaminan kepada para pemangku kepentingan, termasuk pemegang saham, kreditur, karyawan, pemerintah, eksekutif pelanggan dan pemangku kepentingan lainnya. Penelitian tentang tata kelola perusahaan masih merupakan subjek yang menarik untuk belajar. Kegagalan untuk menerapkan GCG dapat memiliki dampak negatif pada perusahaan, mulai dari kinerja rendah runtuhnya perusahaan.

Peningkatan kinerja perusahaan memiliki dampak pada kesejahteraan manajemen dan pemegang saham (pemegang saham) perusahaan. Di sisi lain, manajemen dapat mengambil tindakan melalui 
kebijakan akuntansi yang memiliki dampak positif pada kepentingan mereka sendiri, dan apa manajemen melakukan mungkin memiliki dampak negatif pada kepentingan pemilik perusahaan (Jensen, 1976). Karena itu, implementasi GCG adalah menjadi alternatif untuk mengurangi praktik manajemen laba.

Efektivitas penerapan tata kelola perusahaan sangat tergantung pada peran atau tindakan yang dilakukan oleh unsur-unsur dalam struktur tata kelola perusahaan. Unsur-unsur ini adalah komisaris, apakah independen atau tidak, komite audit, kepemilikan saham institusional, kepemilikan saham dan jasa audit dari reputasi Kantor Akuntan Publik (KAP). Harapannya adalah bahwa lebih efektif peran yang dilakukan oleh unsur-unsur dari struktur tata kelola perusahaan, semakin kualitas informasi akuntansi akan ditingkatkan dari titik pengguna pandang.

\section{Pengertian Good Cooperate Governance}

\section{TINJAUAN PUSTAKA}

Good Cooperate Governance merupakan bentuk manajemen perusahaan yang mencakup bentuk perlindungan bagi pemegang saham (publik) sebagai pemilik perusahaan dan kreditur sebagai dana eksternal , menyatakan bahwa Good Corporate Governance dapat didefinisikan sebagai "hubungan antara berbagai peserta dalam menentukan arah dari dan kinerja perusahaan" (Monks, 2004). Menurut Masyhud Ali di dalam Sochib (2016) Corporate Governance atau tata kelola perusahaan adalah sistem yang digunakan dalam mengarahkan dan mengendalikan kegiatan bisnis perusahaan. Good Corporate Governance juga mengandung pemahaman tentang aturan mengenai pembagian tugas dan tanggung jawab di antara pihak-pihak atau pemain kunci yang berpartisipasi dan memiliki kepentingan yang berbeda dalam perusahaan. Good Corporate Governance adalah metode yang digunakan untuk mengatur hubungan antara berbagai pihak yang berkepentingan (stakeholders) sehingga kesalahan yang signifikan dapat diperbaiki atau diminimalkan. Mekanisme Good Corporate Governance adalah alat yang digunakan oleh manajemen untuk meningkatkan kontrol dan transparansi informasi tentang operasi perusahaan sehingga pengguna (misalnya investor) menjadi lebih percaya diri tentang dana investasi yang mereka berikan (Arlita, 2019)

\section{Prinsip Good Corporate Governance}

Terdapat tiga prinsip dasar GCG sebagai berikut (Wahyudin, 2018):

1) Negara dan instrumen yang membuat undang-undang dan peraturan yang mendukung iklim bisnis yang efisien dan transparan, menerapkan hukum dan peraturan dan menegakkan hukum secara konsisten (penegakan hukum yang konsisten).

2) Dunia usaha sebagai pemain pasar berlaku GCG sebagai pedoman dasar untuk implementasi bisnis.

3) Masyarakat sebagai produk dan layanan dari dunia usaha serta pihak yang terkena dampak keberadaan perusahaan, menunjukkan kepedulian dan melakukan kontrol sosial secara obyektif dan bertanggung jawab.

\section{Manfaat Good Cooperate Governance}

Ada lima manfaat yang dapat diperoleh oleh perusahaan yang menerapkan Good Corporate Governance, yaitu (Syafitri, 2018):

1) GCG tidak akan langsung mendorong penggunaan sumber daya perusahaan secara lebih efektif dan efisien, yang akan membantu menciptakan pertumbuhan atau perkembangan perekonomian nasional.GCG dapat membantu perusahaan dan perekonomian nasional, dalam hal ini menarik modal investor dengan biaya yang lebih rendah melalui peningkatan kepercayaan investor domestik dan internasional dan kreditur.

2) Membantu manajemen perusahaan dalam memastikan / menjamin bahwa perusahaan telah memenuhi ketentuan, hukum dan peraturan.

3) Membangun manajemen dan Perusahaan Boards dalam memantau penggunaan aset perusahaan.

4) Mengurangi korupsi.

\section{Kinerja Keuangan}

Jurnal Insitusi Politeknik Ganesha Medan

Juripol, Volume 4 Nomor 1 Maret 2021 


\section{Pengertian Kinerja Keuangan}

Menurut Sucipto dalam Sochib (2016) Kinerja keuangan adalah langkah-langkah tertentu yang dapat mengukur keberhasilan suatu perusahaan dalam menghasilkan laba. penilaian kinerja yang dilakukan untuk perilaku menekan pantas dan untuk menciptakan dan mewujudkan apa yang diinginkan melalui kinerja dan waktu umpan balik dan imbalan yang baik intrinsik dan ekstrinsik.

Kinerja keuangan merupakan analisis dilakukan untuk melihat seberapa jauh perusahaan telah dilakukan dengan menggunakan aturan pelaksanaan keuangan dengan baik dan benar. Seperti dengan membuat laporan keuangan yang memenuhi standar dan ketentuan dalam SAK (Standar Akuntansi Keuangan) atau GAAP (General Accepted Accounting Principles), dan lain-lain) (Fahmi, 2017).

Menurut (Munawir, 2010) menyebutkan bahwa :" kinerja keuangan perusahaan adalah salah satu kondisi keuangan perusahaan berdasarkan analisis rasio keuangan perusahaan. pihak yang berkepentingan benar-benar membutuhkan hasil pengukuran kinerja perusahaan untuk mengetahui kondisi perusahaan dan tingkat keberhasilan perusahaan dalam menjalankan kegiatan operasionalnya. Kinerja keuangan merupakan faktor yang menunjukkan efektivitas dan efisiensi organisasi dalam rangka mencapai tujuannya. Efektivitas adalah jika manajemen mampu memilih tujuan yang tepat atau alat yang tepat untuk mencapai tujuan yang telah ditetapkan. Sedangkan efisiensi didefinisikan sebagai rasio antara input dan output dengan input tertentu untuk mendapatkan hasil yang optimal.

\section{Tujuan dan Manfaat Kinerja Keuangan}

Menurut (Rudianto, 2006) Kinerja adalah "tekad periodik efektivitas operasional suatu organisasi, yang bagian dari organisasi dan karyawannya berdasarkan yang telah ditentukan tujuan, standar dan kriteria: Tujuan utama dari penilaian ini adalah untuk karyawan memotivasi untuk mencapai tujuan organisasi dan mematuhi telah ditentukan perilaku standar, sehingga tindakan dan hasil yang diinginkan.

Adapun manfaat penilaian kinerja adalah sebagai berikut :

1) Mengelola operasional organisasi secara efektif dan efisien melalui motivasi karyawan yang maksimal.

2) Membantu dalam membuat keputusan yang berkaitan dengan karyawan, promosi, transfer / mutasi, dan pengakhiran.

3) Menginformasikan kebutuhan pelatihan dan pengembangan karyawan untuk memberikan kriteria evaluasi dan program evaluasi karyawan.

4) Memberikan umpan balik bagi karyawan tentang bagaimana mereka menilai kinerja mereka.

5) Memberikan dasar untuk distribusi karyawan.

\section{Tahap-tahap dalam Menganalisis Kinerja Keuangan}

Menurut Fahmi (2017) adapun langkah yang dilakukan dalam analisis keuangan adalah:

1) Untuk meninjau data laporan keuangan. review di sini dilakukan dengan tujuan agar laporan keuangan yang telah dibuat sesuai dengan penerapan aturan umum tingkat dalam dunia akuntansi, sehingga hasil dari laporan keuangan dapat dipertanggungjawabkan.Melakukan perhitungan. Penerapan metode perhitungan disini adalah disesuaikan dengan kondisi dan permasalahan yang sedang dilakukan sehingga hasil dari perhitungan tersebut aka memberikan suatu kesimpulan sesuai dengan analisis yang diinginkan.

2) Membuat perbandingan dengan hasil perhitungan yang telah diperoleh. Dari hasil perhitungan yang telah diperoleh kemudian perbandingan dibuat dengan hasil perhitungan dari berbagai perusahaan lain.

3) Melakukan (menafsirkan) berbagai masalah yang ditemukan. Pada tahap ini, melihat kinerja keuangan perusahaan setelah tahap berikutnya dilakukan untuk melihat apa masalah dan kendala yang dialami perusahaan.

4) Mencari dan memberikan pemecahan masalah (solusi) untuk berbagai masalah yang ditemukan. Pada tahap terakhir, setelah menemukan berbagai masalah yang dihadapi, solusi yang dicari untuk

Jurnal Insitusi Politeknik Ganesha Medan

Juripol, Volume 4 Nomor 1 Maret 2021 
memberikan masukan atau input sehingga apa yang telah rintangan dan hambatan sejauh dapat diselesaikan.

Dalam prakteknya, ada dua jenis metode yang digunakan dalam analisis laporan keuangan yang umum digunakan, yaitu sebagai berikut:

1. Analisis Vertikal (Statis), adalah analisis yang dilakukan hanya untuk satu periode dalam laporan keuangan. Analisis dilakukan antar pos-pos yang ada, dalam satu periode. Informasi yang diperoleh hanya untuk satu periode dan kemajuan tidak diketahui dari periode ke periode.

2. Horizontal (Dynamic) Analysis, adalah analisis yang dilakukan dengan membandingkan laporan keuangan untuk beberapa periode. Dari hasil analisis ini akan melihat perkembangan perusahaan dari satu periode ke periode lain.

Dalam menganalisis kinerja keuangan perusahaan, rasio keuangan adalah nomor yang diperoleh dari perbandingan satu akun laporan keuangan dengan account lain yang memiliki hubungan yang relevan dan signifikan.

\section{Analisis Kinerja Perusahaan}

Analisis terhadap kinerja perusahaan pada umumnya dilakukan dengan menganalisis laporan keuangan, yang mencakup perbandingan kinerja untuk beberapa perode dan mengevaluasi kecenderungan posisi keuangan perusahaan sepanjang waktu.Teknk analisis yang dapat digunakan untuk menilai kinerja perusahaan adalah melalui analisis rasio.

a. Jenis-Jenis Rasio

Menurut (Kasmir, 2018) jenis-jenis analisis Rasio yaitu di antaranya sebagai berikut :

1. Rasio Likuiditas, adalah rasio yang menggambarkan kemampuan perusahaan untuk memenuhi kewajiban jangka pendek (utang). Termasuk rasio lancar, rasio (rasio uji asam) sangat saat ini atau rasio cepat (quick ratio), rasio kas (cash ratio), rasio perputaran kas dan persediaan untuk modal kerja bersih.

2. Rasio solvabilitas atau leverage, adalah rasio yang digunakan untuk mengukur sejauh mana aset perusahaan dibiayai dengan utang. Termasuk Dept Untuk Aset Ratio (Rasio Utang), Dept Untuk Equity Ratio, Long Term Debt Dan Untuk Equity Ratio, Time Interest Earned, dan Fixed Cakupan Charge.

3. Rasio Aktivitas, adalah rasio yang digunakan untuk mengukur efektivitas perusahaan dalam menggunakan aset dicari. Atau bisa dikatakan rasio ini digunakan untuk mengukur sumber daya perusahaan. Termasuk Perputaran Piutang (Piutang Perputaran), rata-rata hari penagihan piutang (piutang Day), perputaran persediaan (Inventory Turnover), hari rata-rata pengumpulan persediaan (Harian Inventory), perputaran modal kerja (Capital Turnover Kerja), perputaran aktiva tetap (Fixed Perputaran Aset), Perputaran Aset (Asset Turnover).

4. Rasio Profitabilitas, adalah rasio yang digunakan untuk menilai kemampuan perusahaan untuk mencari keuntungan. Termasuk Profit Margin (Margin Penjualan), Return On Investment (ROI), Return on Equity (ROE), earning per share (Earning per share)

b. Return On Investment (ROI)

1. Return On Investnent (ROI) merupakan kemampuan perusahaan untuk menghasilkan keuntungan yang akan digunakan untuk menutup Investasi yang dikeluarkan. Laba yang digunakan untuk mengukur rasio ini adalah laba bersih setelah pajak atau EAT (Riandi,2011)

2. Menurut Munawir (2010:89) dalam Syarifudin (2017) Return On Investment merupakan bentuk dari rasio profitabilitas yang digunakan untuk mengukur kemampuan perusahaan dalam menghasilkan keuntungan yang berasal dari keseluruhan dana pada aktiva yang digunakan untuk operasional perusahaan ROI sebagai perhitungan yang memungkinkan suatu usaha untuk menentukan jumlah usaha yang diterima dari jumlah penanaman sebuah modal yang berupa uang atau sumber daya.

3. Rumus yang digunakan dalam pengukuran ROI menurut Kasmir (2018:136) sebagai berikut :

Jurnal Insitusi Politeknik Ganesha Medan

Juripol, Volume 4 Nomor 1 Maret 2021 


$$
\text { ROI }=\frac{\text { Earning After intrest and Tax }}{\text { Total Assetss }}
$$

\section{METODE PENELITIAN}

Penelitian ini adalah penelitian kualitatif dengan metode kajian literature. Menurut (Marzali, 2016) Kajian literatur adalah satu bentuk penelitian kepustakaan dengan membaca berbagai jenis buku dan jurnal, dan sejenisnya yang berkaitan dengan topik pembahasan penelitian guna untuk menghasilkan sebuah karya tulisan ilmiah, seperti skripsi, tesis, dan disertasi. Penulis mencari literatur yang sesuai dengan topik dan pembahasan penelitian, tentang masyarakat dan wilayah penelitian, tentang teori-teori yang digunakan dan dihasilkan yang berkaitan dengan topik penelitian yang akan diteliti, tentang metode penelitian yang digunakan dan seterusnya.

\section{PEMBAHASAN}

Nilai perusahaan dapat menggambarkan keadaan suatu perusahaan. Semakin baik nilai suatu perusahaan, maka tersebut perusahaan akan dipandang baik oleh para calon investor (Irvian, 2016).

Dengan diterapkannya GCG di suatu perusahaan dan dengan adanya komite audit maka hal tersebut berpengaruh terhadap penghindaran pajak. Dalam hal ini dijelaskan bahwa komite audit independent dalam menjalankan tugasnya melakukan pengendalian internal perusahaan serta memonitor dan mengawasi dijalankan dengan baik sehingga penghindaran pajak oleh perusahaan tidak terjadi pada perusahaan. Namun dengan adanya praktik penghindaran pajak tersebut dimata investor tidak menurunkan nilai perusahaan. Selain itu, praktik penghindaran pajak tersebut masih memenuhi aturan perpajakan (hukum) (Christina, 2020)

Pelaksanaan Good Corporate Governance merupakan konsep yang menekankan pentingnya hak pemegang saham untuk memperoleh informasi dengan benar, akurat, dan tepat waktu. Namun pemahaman menyeluruh tentang state-of-artdari Good Corporate Governance diperlukan (Nurjamilah, 2018)

\section{KESIMPULAN}

Berdasarkan beberapa penelitian di atas, dapat dikatakan bahwa setiap tujuan untuk menciptakan sebua Hasil yang diperoleh adalah bahwa Good Corporate Governance memiliki pengaruh dalam meningkatkan corporate value. Praktik manajemen laba akan berdampak pada kredibilitas laporan keuangan. Kinerja Keuangan dan Kinerja Saham yang dicapai perusahaan tergolong baik, terlihat dari nilainilai yang digunakan sebagai indikator untuk merefleksikan Kinerja Keuangan dan Kinerja Saham. Penerapan Tata Kelola Perusahaan seharusnya dapat meningkatkan patuhnya perusahaan terhadap aturanaturan yang berlaku untuk mencapai tujuan perusahaan.

\section{Ucapan Terima Kasih}

Terimakasih penulis sampaikan kepada Allah SWT. yang hanya karena ridho dan rahmatNya penulis dapat menyelesaikan tulisan ini. Tidak lupa penulis ucapkan terimakasih kepada kedua orang tua yang selalu memberikan dukungan tiada henti bagi penulis hingga kini. Serta kepada Dosen Perkuliahan Manajemen Keuangan Lanjutan Prof.Dr.Isfenti Sadalia, S.E, M.E atas segala ilmu-ilmu yang telah diberikan selama perkuliahan ini sehingga penulis dapat membuat sebuah tulisan mengenai tata kelola perusahaan, penulis ucapkan terimakasih.

\section{REFERENSI}

Arlita, R. B. (2019). Pengaruh good corporate governance dan leverage terhadap praktik manajemen laba.

Christina, R. P. (2020). Pengaruh Good Corporate Governance dan Ukuran Perusahaan terhadap Profitabilitas pada Perbankan yang Terdaftar di BEI. . Jurnal Darma Agung. Vol 28 No 2. 
Fahmi, I. (2017). Analisis Kinerja Keuanga. Bandung: Alfabeta.

Irvian, S. I. (2016). Pengaruh Penerapan Konsep Good Corporate GovernanceTerhadap Kinerja NonKeuangan di Kantor Pusat PT Asuransi Jasa Indonesia. . Jurnal Manajemen dan Organisasi. Vol. VII. No. 2.

Jensen, M. \&. (1976). Theory of the Firm: Managerial Behavior, Agency Cost and Ownership Structure. Journal of Financial Economics,3(4, 305-360.

Kasmir. (2018). Pengantar Manajemen Keuangan. Jakarta: Kencana.

Marzali, A. (2016). Menulis kajian literatur. Jurnal Etnosia , Vol 01 (02), 27-36.

Monks, R. a. (2004). Corporate Governance. Cambridge: Blackwell Business.

Munawir. (2010). Analisis Laporan Keuangan. Edisi Empat. Yogyakarta: Liberty.

Nurjamilah, M. R. (2018). Studi Tata Kelola Perusahaan yang Baik melalui Kinerja Perusahaan: Studi Pemetaan Sistematik. Jurnal Saintifik Manajemen dan Akuntansi Vol. 1 No. 2, 63-81.

Rudianto. (2006). Akuntansi Manajemen. Jakarta.

Sochib. (2016). Good Corporate Governance Manajemen Laba dan Kinerja Keuanga. Penerbit Deepublish.

Syafitri, N. (2018). Pengaruh Good Corporate Governance dan Leverage terhadap Manajemen Laba pada perusahaan sub sektor Asuransi yang Terdaftar di Bursa Efek Indonesia.

Wahyudin, Z. (2018). Good Corporate Governance. Bandung: Alfabeta. 